\title{
Probable vertical transmission identified within six hours of life
}

\author{
Fabrício Silva Pessoa ${ }^{1}$ \\ DMarynéa Silva do Vale ${ }^{2}$ \\ (iD) Patrícia Franco Marques ${ }^{2}$ \\ (iD) Susana da Silva Figueira² \\ (Di) Izabel Athayde da Silva Cruz Salgado' \\ (D) Roberta de Sousa Wernz Cancian Moche ${ }^{3}$
}

\begin{abstract}
1. Infectologista Pediátrico. Serviço de Infectologia Pediátrica do Hospital Universitário da Universidade Federal do Maranhão, São Luis, MA, Brasil. 2. Neonatologista. Unidade de Cuidados Intensivos Perinatais do Hospital Universitário da Universidade Federal do Maranhão, São Luis, MA, Brasil. 3. Pediatra. Unidade de Cuidados Intensivos Perinatais do Hospital Universitário da Universidade Federal do Maranhão, São Luis, MA, Brasil.
\end{abstract}

http://dx.doi.org/10.1590/1806-9282.66.12.1621

\section{SUMMARY}

We present the case of 33 weeks + weeks pregnant patient (GIPO), with proven COVID-19 infection by RT-PCR and, at admission, she presented with a dry cough and "tiredness when talking,". Chest computed tomography was performed, which showed the presence of attenuations with ground glass opacification and bilateral consolidations. She then had a cesarean section because of maternal respiratory decompensation. She was transferred to the ICU of the same hospital with an $\mathrm{O} 2$ catheter. The newborn was transferred to the neonatal ICU of the same hospital in ambient air and maintained in respiratory and contact isolation. RT-PCR was collected for SARS-COV-2 at 6 $h$ of life, which was positive. Faced with the knowledge gap on vertical transmission, RT-PCR for SARS-COV-2 at 6 h of life gives cause for concern, thus representing the possibility of vertical transmission by SARS-COV-2, although additional investigations are required.

KEYWORDS: Betacoronavirus. Coronavirus infections. Infant, newborn. Infectious disease transmission, vertical.

\section{INTRODUCTION}

A major concern is raised by COVID-19 during pregnancy and the potential transmission of infection from mother to child before, during, and after childbirth. Generally, transmitting respiratory viruses to newborns mostly occurs via the birth canal and during breastfeeding or close contact among healthcare providers or family members ${ }^{1}$. The possibility of vertical transmission through breastfeeding or the consumption of human milk is important. In light of current scientific data, the breast milk of a COVID-19-positive mother is not yet considered a transmission vehicle. Although the detection of SARS-COV-2 in human milk may be possible, additional research is required to assess its potential risk for viral transmission and whether this will be sufficient to cause COVID-19 disease in the newborn. It has been speculated that specific SARS-COV-2 antibodies pass through breast milk from a COVID-19-positive mother to the neonate within a few days after the onset of the disease, thus possibly modulating the clinical expression of the infant's infection. When mothers with COVID-19 are extremely sick to care for the newborns, the newborn is separately managed and fed freshly extracted breast milk without the requirement to pasteurize

DATE OF SUBMISSION: 03-Aug-2020

DATE OF ACCEPTANCE: 08-Aug-2020

CORRESPONDING AUTHOR: Fabrício Silva Pessoa

Prevenção e Controle de Infecções Hospitaleres, Segurança do Paciente, Hospital Universitário

Universidade Federal do Maranhão, Rua Silva Jardim, s/nº, São Luís, MA, Brasil

Tel: +55 98 98158-3800

E-mail: fabriciosilvapessoa@hotmail.com 
it. Moreover, preventive procedures such as hand hygiene and the use of a face mask during feedings are recommended ${ }^{2,3}$. In this context, we report the case of neonatal infection by COVID-19 in a neonatal unit in which the mother was confirmed as having COVID-19 and the newborn was RT-PCR-positive at $6 \mathrm{~h}$ of life, thus suggesting the possibility of vertical transmission of SARS-COV-2. The clinical manifestations of the mother were severe while those of the newborn were mild with good clinical evolution.

\section{CASE}

A mother, 34 years old, of mixed race, a nurse, primiparous (G1POAO), with a gestational age of 33 weeks and 6 days, identified by ultrasound at a few weeks of gestational age, was admitted to the obstetric center of a university hospital in the northeast region of Brasil on April 21, 2020, at 01:24 h, with flu-like symptoms (rhinorrhea, myalgia, fever $>38^{\circ} \mathrm{C}$ and odynophagia), which started seven days prior and progressed with gradual worsening of the condition and dyspnea. During admission, the patient had a dry cough and "tiredness when talking," and she was already using medication such as hydroxychloroquine and azithromycin. She had five prenatal appointments, Blood Typing $\mathrm{B}+$, denied hypertension, reported gestational diabetes with dietary control, with negative TORCH serology. She received two doses of antenatal corticosteroid. Chest computed tomography was performed, showing the presence of attenuations with ground glass opacification and bilateral consolidation. Cesarean section was performed because of maternal respiratory decompensation (suspected of having COVID-19) on April 22, 2020, at 01:44 h, and the mother was transferred to the ICU of the same hospital, with an $\mathrm{O}_{2}$ catheter. All respiratory isolation and protective equipment measures and care were adopted by the team of health professionals during the cesarean section. The newborn presented good vitality at birth, with Apgar 9/9, and without the requirement for neonatal resuscitation maneuvers; the birth weight was $2370 \mathrm{~g}$, head circumference of $33 \mathrm{~cm}$, and a length of $43 \mathrm{~cm}$. The newborn was transferred to the neonatal unit, maintained in ambient air, kept in respiratory and contact isolation, and the RT-PCR was collected for SARS-COV-2 at $6 \mathrm{~h}$ of life, which came back positive. During hospitalization, the newborn presented episodes of regurgitation, which satisfactorily progressed, as well as jaundice of prematurity, and was put on phototherapy. Chest CT was performed with normal results and a new RT-PCR swab was collected for SARS-COV-2, which was negative. The infant was discharged at 10 days of life, clinically well, with verbal and written guidance to maintain isolation until 14 days and on other hygiene measures to prevent transmission of the virus.

\section{DISCUSSION}

The literature published to date has not yet confirmed vertical transmission of SARS-COV-2, although this possibility is considered. Similarly, there have been no reports of viral RNA identified in vaginal secretions and amniotic fluid; however, it has recently been found in breast milk ${ }^{4,5}$. Because IgM immunoglobulin is a macromolecule and therefore does not cross the placental barrier, its detection in the first seven days of life suggests intra-uterine infection, similar to the case reported herein. However, Chen et al. ${ }^{6}$ questioned the absence of morphological changes related to infection in the placenta. Li et al. ${ }^{7}$ reported the case of a neonate with a positive RT-PCR nasopharyngeal swab for SARS-COV-2 at three days of life and questioned whether the newborn was not infected after birth, either by the mother or other family members or by professional caregivers in the hospital. Wang et al. ${ }^{8}$ reported a case of neonatal infection by COVID-19 in China, in which the laboratory results were negative (including research for Legionella pneumophila, Chlamydia pneumoniae, Mycoplasma pneumoniae, Q rickettsia fever, adenovirus, respiratory syncytial virus, influenza A virus influenza B virus, and parainfluenza virus $1 / 2 / 3$ ) with favorable clinical outcomes. In this reported case, the result of the pharyngeal swab for SARS-COV-2 was positive $36 \mathrm{~h}$ after birth. As in our case, strict measures were considered to reduce the risk of infection. Although COVID-19 was detected by RT-PCR in the maternal peritoneal fluid collected during cesarean section in 28 patients with SARS, the researchers could not rule out the possibility of another contact transmission of the newborn. They concluded that clinical data on COVID-19 infection in newborns is still very limited, and it is still unclear whether SARS-COV-2 can be vertically transmitted through the placenta or what are the short- and longterm damage it causes ${ }^{8}$. Infection by SARS-COV-2 may occur as Late Neonatal Sepsis, probably through nosocomial transmission in the nursery or Neonatal Intensive Care Unit ${ }^{9}$. Late neonatal sepsis occurs 
after $48 \mathrm{~h}$, and it is essential to collect neonatal samples in the first hours of life to signal the possibility of vertical transmission of newborns to mothers with suspected or confirmed COVID-19 ${ }^{10}$. Dong et al. ${ }^{11}$ reported high levels of IgM antibodies in the newborn of a mother with COVID-19, thus suggesting that infection occurred in the uterus since IgM antibodies do not cross the placental barrier. However, the RT-PCR for SARS COV-2 with samples of nasopharyngeal swabs from the newborn were repeatedly negative, which did not demonstrate the presence of the virus. Zeng et al. ${ }^{12}$ reported six newborns with negative RT-PCR for SARS-COV-19 born to mothers with confirmed COVID19 , thus demonstrating the diagnostic limitation of vertical transmission because no RNA particles of the virus were identified. Zhu et al. ${ }^{1}$ retrospectively analyzed the clinical characteristics of ten newborns from nine mothers with confirmed COVID-19 infection in five hospitals from January 20 to February 5, 2020, in Wuhan, a city in the province of Hubei. Of the studied newborns, four were born full-term and six were premature. Clinical findings demonstrated that the first symptom in newborns was shortness of breath, as well as initial symptoms such as fever, thrombocytopenia accompanied by impaired liver function, tachycardia, vomiting, and pneumothorax. Samples of pharyngeal swabs were collected for nucleic acid amplification tests for SARS-COV-2, nine days after birth, all with negative results. The conclusion of the research in these newborns was that 2019-nCoV perinatal infection may have adverse effects in newborns and cause problems during pregnancy, such as fetal distress, premature labor, respiratory distress syndrome, and thrombocytopenia, together with changes in liver function and even death. However, the vertical transmission of 2019-NCOV has not yet been confirmed' Moreover, cases of neonatal infection by SARS-COV-2 were reported in China, the youngest being $30 \mathrm{~h}$ after birth, longer than the case reported herein, which had a positive result at $6 \mathrm{~h}$ of life. Hong et al. ${ }^{13}$ reported that the newborns probably acquired SARS-COV-2 infection through close contact with infected mothers. In their publication, they described the criteria adopted in their hospital for the clinical diagnosis of SARSCOV-2 in the neonatal population such as at least one clinical symptom, including body temperature instability, hypoactivity, refusal of food or dyspnoea; chest X-rays showing abnormalities, including unilateral or bilateral ground-glass opacities; (3) diagnosis of SARSCOV-2 in relatives or caregivers; and close contact with persons suspected or confirmed for SARS-COV-2 infection, patients with unexplained pneumonia ${ }^{13}$. In a cohort study conducted by Zeng et al. ${ }^{14}$, with 33 newborns of mothers with COVID-19 in Wuhan, China, 3 out of 33 children (9\%) had early onset of SARS-COV-2 infection, and the authors reported that the sources of SARS-COV-2 contamination in the newborns were probably of material origin, bearing in mind the rigorous preventive procedures implemented during childbirth, as reported in our case.

\section{CONCLUSION}

In this case report, we described a neonate, with strong evidence that this is a case of intrauterine vertical transmission in a neonatal unit in the Northeast of Brasil, which was demonstrated by the presence of the virus at only $6 \mathrm{~h}$ of life. Thus, it is essential to perform RT-PCR collection for COVID-19 in the first few hours of life. The maternal severity of the disease and the enormous viral replication that occurred in the mother may have led to probable in-utero transmission to the newborn.

\section{Acknowledgments}

We thank the patient and her family for granting permission to publish this article.

\section{Author's Contribution}

All authors have made a significant contribution to the findings and methods in the paper. All authors have read and approved the final draft. All authors have certified that the manuscript is original and that no portion is under consideration elsewhere or has been previously published in any form other than as an abstract. All authors have no conflict of interest. 


\section{RESUMO}

Apresentamos o caso de uma paciente grávida de 33 semanas + (G1PO), com infecção de COVID-19 comprovada por RT-PCR que, na admissão, apresentava tosse seca e "cansaço ao falar". Foi realizada tomografia computadorizada do tórax, que mostrou a presença de atenuações com opacidade em vidro fosco e consolidações bilaterais. Ela então passou por uma cesariana devido a descompensação respiratória materna. Em seguida, foi transferida para a UTI do mesmo hospital com um cateter de O2. O recém-nascido foi transferido para a UTI neonatal do mesmo hospital, em ar ambiente, e mantido em isolamento respiratório e de contato. Material para o RT-PCR para SARS-COV-2 foi coletado às 6 h de vida, e o resultado do teste foi positivo. Perante a lacuna de conhecimento sobre a transmissão vertical, o resultado positivo do RT-PCR para SARS-COV-2 às 6 h de vida é motivo de preocupação, pois representa uma possível transmissão vertical do SARS-COV-2, embora investigações adicionais sejam necessárias.

PALAVRAS-CHAVE: Betacoronavirus. Infecções por coronavirus. Recém-nascido. Transmissão vertical de doença infecciosa.

\section{REFERENCES}

1. Zhu H, Wang L, Fang C, Peng S, Zhang L, Chang G, et al. Clinical analysis of 10 neonates born to mothers with 2019-nCoV pneumonia. Transl Pediatr. 2020;9(1):51-60

2. Davanzo R, Moro G, Sandri F, Agosti M, Moretti C, Mosca F. Breastfeeding and coronavirus disease-2019: ad interim indications of the Italian Society of Neonatology endorsed by the Union of European Neonatal \& Perinatal Societies. Matern Child Nutr. 2020;16(3):e13010.

3. Lackey KA, Pace RM, Williams JE, Bode L, Donovan SM, Järvinen KM, et al. SARS-CoV-2 and human milk: what is the evidence? Matern Child Nutr. 2020;e13032.

4. Duran P, Berman S, Niermeyer S, Jaenisch T, Forster T, Gomez Ponce de Leon R, et al. COVID-19 and newborn health: systematic review. Rev Panam Salud Publica. 2020;44:e54.

5. Groß R, Conzelmann C, Müller JA, Stenger S, Steinhart K, Kirchhoff F, et al. Detection of SARS-CoV-2 in human breastmilk. Lancet. 2020;395(10239):1757-8.

6. Chen S, Huang B, Luo DJ, Li X, Yang F, Zhao Y, et al. Pregnancy with new coronavirus infection: clinical characteristics and placental pathological analysis of three cases. Zhonghua Bing Li Xue Za Zhi. 2020;49(5):418-23.

7. Li M, Xu M, Zhan W, Han T, Zhang G, Lu Y. Report of the first cases of mother and infant infections with 2019 novel coronavirus in Xinyang City Henan Province. Chin J Infect Dis. 2020;38:E007.
8. Wang S, Guo L, Chen L, Liu W, Cao Y, Zhang |, et al. A case report of neonatal 2019 coronavirus in China. Clin Infect Dis. 2020;71(15):853-7.

9. Coronado Munoz A, Nawaratne U, McMann D, Ellsworth M, Meliones ], Boukas K. Late-onset neonatal sepsis in a patient with COVID-19. N Engl | Med. 2020;382(19):e49.

10. Organização Pan-Americana da Saúde. Centro Latino-Americano de Perinatologia, Saúde da Mulher e Reprodutiva. Prevenção de infecções relacionadas à assistência à saúde em neonatologia. Montevidéu: CLAP/SMR-OPS/ OMS; 2016. [cited 2020 Aug 1]. Available from: https://portaldeboaspraticas. iff.fiocruz.br/wp-content/uploads/2018/04/clap1613-03.pdf

11. Dong L, Tian J, He S, Zhu C, Wang J, Liu C, et al. Possible vertical transmission of SARS-CoV-2 from an infected mother to her newborn. JAMA. 2020;323(18):1846-8.

12. Zeng H, Xu C, Fan J, Tang Y, Deng Q, Zhang W, et al. Antibodies in infants born to mothers with COVID-19 pneumonia. JAMA. 2020;323(18):1848-9.

13. Hong $\mathrm{H}$, Wang $\mathrm{Y}$, Chung HT, Chen C). Clinical characteristics of novel coronavirus disease 2019 (COVID-19) in newborns, infants and children. Pediatr Neonatol. 2020;61(2):131-2.

14. Zeng L, Xia S, Yuan W, Yan K, Xiao F, Shao J, et al. Neonatal early-onset infection with SARS-CoV-2 in 33 neonates born to mothers with COVID-19 in Wuhan, China. JAMA Pediatr. 2020;174(7):722-5. 